\title{
Turbine Airfoil Leading Edge Film Cooling Bibliography: 1972-1998
}

\author{
D.M. KERCHER*
}

GE Aircraft Engines, M/S 240-GH, 1000 Western Ave., Lynn, MA 01910, USA

(Received 10 March 1999; In final form 7 May 1999)

\begin{abstract}
Film cooling for turbine airfoil leading edges has been a common practice for at least 35 years as turbine inlet gas temperatures and pressures have continually increased along with cooling air temperatures for higher engine cycle efficiency. With substantial engine cycle performance improvements from higher gas temperatures, it has become increasingly necessary to film cool nozzle and rotor blade leading edges since external heat transfer coefficients and thus heat load are the highest in this airfoil region. Optimum cooling air requirements in this harsh environment has prompted a significant number of film cooling investigations and analytical studies reported over the past 25 years from academia, industry and government agencies. Substantial progress has been made in understanding the complex nature of leading edge film cooling from airfoil cascades, simulated airfoil leading edges and environment. This bibliography is a report of the open-literature references available which provide information on the complex aero-thermo interaction of leading edge gaseous film cooling with mainstream flow. From much of this investigative information has come successful operational leading edge film cooling design systems capable of sustaining airfoil leading edge durability in very hostile turbine environments.
\end{abstract}

Keywords: Film cooling, Airfoil cooling, Leading edge, Gas turbine

1972-1979

Agachev, R.S. and Kumirov, B.A., 1978, "Theoretical experimental analysis of influence of coolant discharge from perforated turbine vanes on their aerodynamic characteristics," Soviet Aeronautics, 21(1), 5-9. ${ }^{\dagger}$

Berenfeld, A., 1978, "Aerodynamic and heat transfer characteristics of film-cooled turbine blades," M.S. Thesis, Massachusetts Institute of Technology.

Emin, O.N., Kutysh, I.I. and Shvartsman, P.I., 1978, "Experimental study of the gasdynamic characteristics of a stator cascade with cooling air discharge through the vane surface," SovietAeronautics, 21(3), 31-36.

Hanus, G.J., 1976, "Gas film cooling of a modeled high pressure, high temperature turbine vane with injection in the leading edge from a single row of spanwise angled coolant holes," Ph.D. Thesis, Purdue University.

Hanus, G.J. and L'Ecuyer, M.R., 1976, "Turbine vane gas film cooling with injection in the leading edge region. from a single row of spanwise angled holes," NASA CR-147160; also Purdue University, Mechanical Engineering Department, Technical Report TSPC-TR76-1.

\footnotetext{
* Tel.: 781-594-1802. Fax: 781-594-0935. E-mail: david.kercher@ae.ge.com

${ }^{\dagger}$ Inclusive leading edge film with other film cooling.
} 
Hanus, G.J. and L'Ecuyer, M.R., 1976, "Turbine vane leading edge gas film cooling with spanwise angled coolant holes," AIA $A$ 76-43.

Hanus, G.J. and L'Ecuyer, M.R., 1977, "Leading-edge injection for film cooling of turbine vanes," AIAA, Journal of Energy, 1(1), 44-49 (condensed version of AIAA 76-43).

Hess, W.G., 1978, "Advanced cooled turbine airfoil aerodynamic investigation," AIAA, Journal of Aircraft, 15(9), 582$588 .^{\dagger}$

Hess, W.G., 1979, "Laminated turbine vane design and fabrication," NASA CR-159655. ${ }^{\dagger}$

Hiroki, T. and Katsumata, I., 1974, "Design and experimental studies of turbine cooling," ASME, 74-GT-30.

Kruse, H., 1978, "Investigation on temperature distribution near film cooled airfoils," High Temperature Problems in Gas Turbine Engines, AGARD-CP-229, Paper No. 8.

Luckey, D.W. and L'Ecuyer, M.R., 1976, "Stagnation region gas film cooling: spanwise angled coolant injection," NASA CR-153398; also Purdue University, Mechanical Engineering Department, Technical Report TSPC-TR-76-2.

Luckey, D.W., Winstanley, D.K., Hanus, G.J. and L'Ecuyer, M.R., 1977, "Stagnation region gas film cooling for turbine blade leading edge applications," AIAA, Journal of Aircraft, 14, 494-501.

Mirhosseini, A. and Barrow, H., 1979, "An experimental determination of heat transfer near the leading edge of a film-cooled gas turbine blade," International Journal of Heat and Fluid Flow, 1(4), 155-159.

Rastogi, A.K. and Whitelaw, J.H., 1972, "Film cooling from a row of holes located along a cylinder in cross flow," Imperial College of Science and Technology, Mechanical Engineering Department, ET/TN/A/17.

Sakata, K., Usui, H. and Takahara, K., 1978, "Cooling characteristics of film-cooled turbine vane having multi-row of ejection holes," ASME, 78-GT-21.

Saryal, N., Ghantous, I.N. and Citci, A., 1978, "Erosion prevention and film cooling on vanes," High Temperature Problems in Gas Turbine Engines, AGARD-CP-229, Paper No. 9.

Sasaki, M. and Kumagai, T., 1973, "A basic experiment of film cooling on the leading edge of the air-cooled turbine blade," 13 th Annual Jet Engine Conference, Aero-Engine Symposium of Japan (ASJ).

Sasaki, M., Takahara, K. and Kumagai, T., 1974, "Preliminary experiments on the film cooling of turbine blades with injection near the leading edge. I - injection through holes located near the leading edge," National Aerospace Lab, NAL-TP-371 (in Japanese).

Sasaki, M., Takahara, K., Sakata, K. and Kumagai, T., 1976, "Study on film cooling of turbine blades: I - experiments on film cooling with injection through holes near leading edge," Bulletin of Japan Society of Mechanical Engineers (JSME), 19(137), 1344-1352 (in Japanese with English abstract).

Suo, M., Patrick, W.P. and Johnson, B.V., 1979, "Particle trajectories near an airfoil with a film-cooled leading edge," AIA A, Journal of Energy, 3, 156-160.

Tabakoff, W. and Hamed, A., 1975, "Theoretical and experimental study of flow through turbine cascades with coolant flow injection," $A I A A 75-843$.

Takahara, K., Minoda, M., Nouse, H., Yoshida, T., Sasaki, M., Yamamoto, A. and Sakata, K., 1974, "High temperature turbine researches at national aerospace laboratory in Japan," ASME, 74-GT-16.

Taylor, A.M.K.P. and Whitelaw, J.H., 1978, "Effectiveness of leading-edge cooling arrangements," Heat Transfer 1978 -
Proceedings of 6th International Heat Transfer Conference, Hemisphere Publishing Corp., Vol. 5, pp. 267-272.

Yoshida, T., Minoda, M., Sakata, K., Nouse, H., Takahara, K. and Matsuki, M., 1976, "Low- and high-speed cascade tests of air-cooled turbine blades," ASME, 76-GT-40.

\section{0-1989}

Anderson, A.T., 1985, "Velocity and temperature profiles in leading-edge film cooling of gas turbine blades," M.S Thesis, Rensselaer Polytechnic Institute.

Araki, T., Nakata, Y., Ito, S., Fukuyama, Y. and Otomo, F., 1987, "High temperature wind tunnel testing of film cooled blades," Proceedings of the 1987 International Gas Turbine Congress, Vol. 3, Gas Turbine Society of Japan, 87-TokyoIGTC-63, pp. $143-150 .^{\dagger}$

Azim, O.A., Hanna, S.F., Awad, M.M. and Matta, N.S., 1985, "Flow visualization and thermal mapping on film cooled turbine blade leading edge," 8th National Heat and Mass Transfer Conference, Oxford \& IBH Publishing Co., HMTC25-85, pp. $181-187$

Bonnice, M.A. and L'Ecuyer, M.R., 1983, "Stagnation region gas film cooling - effects of dimensionless coolant temperature," NASA CR-168197; also M.A. Bonnice, 1982, M.S Thesis, Purdue University.

Bunker, R.S., 1988, "Airfoil leading edge impingement cooling including effects of film cooling bleed (Turbine Blade, Heat Transfer)," Ph.D. Thesis, Arizona State University.

Camci, C., 1985, "Experimental and theoretical study of film cooling on a gas turbine blade," Ph.D. Thesis, Katholieke University, Leuven.

Camci, C. and Arts, T., 1985, "Experimental heat transfer investigation around the film-cooled leading edge of a highpressure gas turbine rotor blade," ASME, Journal of Engineering for Gas Turbines and Power, 107, 1016-1021.

Camci, C., Arts, T. and Breugelmans, F.A.E., 1985, "Experimental convective heat transfer investigation around a film cooled high pressure turbine blade," 7th International Symposium on Air Breathing Engines (ISABE), AIAA Publications, ISABE 85-7035, pp. 331-338. ${ }^{\dagger}$

Cheng, J.-R. and Ji, H.-H., 1986, "Experimental investigation on the composite cooling of a semicylinder leading edge," Heat Transfer 1986 - Proceedings of The 8th International Heat Transfer Conference, Vol. 3, C.L. Tien et al. (Eds.), Paper No. JW-12, pp. 1219--1224.

Chu, T., Brown, A. and Garrett, S., 1985, "Discharge coefficients of impingement and film cooling holes," $A S M E, 85-\mathrm{GT}-81$.

EI-Hadik, A.A.B., 1980, "An investigation of flow and heat transfer around the leading edge of a film-cooled gas turbine blade," Ph.D. Thesis, University of Liverpool.

El-Hadik, A.A.B. and Barrow, H., 1981, "A theoretical and experimental investigation of flow and heat transfer in film cooling," Proceedings of 2nd International Conference on Numerical Methods in Thermal Problems, Vol. 2, Pineridge Press, pp. 1246-1256.

El-Hadik, A.A., Awad, M.M. and Araid, F.F., 1983, “A numerical solution for turbulent flow around the leading edge of a film cooled gas turbine blade," ASME/JSME Thermal Engineering Joint Conference Proceedings, Vol. 4, Y. Mori and W.-J. Yang (Eds.), pp. 199-204.

Hylton, L.D., 1985, "Film cooling heat transfer on a turbine airfoil," Turbine Engine Hot Section Technology (HOST), NASA CP-2405, pp. 151-159. 
Hylton, L.D., 1986, "Turbine airfoil film cooling," Turbine Engine Hot Section Technology (HOST), NASA CP-2444, pp. $237-241 .^{\dagger}$

Hylton, L.D., Nirmalan, V., Sultanian, B.K. and Kaufman, R.M., 1987, "Turbine airfoil film cooling," Turbine Engine Hot Section Technology (HOST), NASA CP-2493, pp. 225-238. ${ }^{\dagger}$

Hylton, L.D., Nirmalan, V., Sultanian, B.K. and Kaufman, R.M., 1988, "The effects of leading edge and downstream film cooling on turbine vane heat transfer," NASA CR$182133 .^{\dagger}$

Ji, H.-H., 1985, "A simulated experimental investigation of the composite cooling of a turbine vane leading edge," M.S. Thesis, Nanjing Aeronautics Institute (in Chinese).

Ji, H. and Zheng, J., 1986, "An experimental investigation of composite cooling on the leading edge region of a turbine blade," Journal of Engineering Thermophysics, 7, 147-150 (in Chinese with English abstract).

Karni, J., 1985, "Endwall boundary layer, cylinder diameter Reynolds number, and surface injection effects on local mass transfer from a cylinder in crossflow," Ph.D. Thesis, University of Minnesota.

Kikkawa, S. and Iwasaki, Y., 1985, "Experimental Investigation on film cooling of gas turbine cascade," Heat TransferJapanese Research, 14(2), 30-44; also 1984, Transaction of the Japan Society of Mechanical Engineers (JSME) (B), 50(455), 1761-1767 (in Japanese)

Kollen, O. and Koschel, W., 1985, "Effect of film cooling on the aerodynamic performance of a turbine cascade," Heat Transfer and Cooling in Gas Turbines, AGARD-CP-390, Paper No. 39.

Kong, Z.-K., 1987, "A simulating experiment of heat transfer coefficients along the leading edge of a film-cooled blade and the establishment of data acquisition and procession system," M.S. Thesis, Nanjing Aeronautical Institute.

Kong, Z.-K. and Zheng, J.-R., 1988, "An experimental investigation of external heat transfer coefficients on leading edge of film cooled turbine blade," Heat Transfer Science and Technology 1988, Hemisphere Publishing Corp., B.-X. Wang (Ed.), pp. 512-517; also 1990, Journal of Propulsion Technology, pp. 25-30 (in Chinese with English abstract)

Kumagai, T., Yoshida, T. and Matsuki, M., 1989, "Cooling characteristics of a radial wafer blade," 9th International Symposium on Air Breathing Engines (ISABE), AIAA Publications, F.S. Billig (Ed.), Vol. 2, ISABE 89-7071, pp. $680-686^{\dagger}$.

Louis, J.F., 1981, "Heat transfer in turbines," Massachusetts Institute of Technology, Department of Aeronautics and Astronautics, Air Force Wright Aeronautical Laboratories, AFWAL-TR-81-2099.

Luckey, D.W., 1980, "Stagnation region gas film cooling: spanwise angled injection from multiple rows of holes," Ph.D. Thesis, Purdue University.

Luckey, D.W. and L'Ecuyer, M.R., 1981, "Stagnation region gas film cooling - spanwise angled injection from multiple rows of holes," NASA CR-165333.

Mick, W.J., 1983, "An experimental study of stagnation region film cooling for application to gas turbine airfoils," M.S. Thesis, Rensselaer Polytechnic Institute.

Mick, W.J. and Mayle, R.E., 1988, "Stagnation film cooling and heat transfer, including its effect within the hole pattern," ASME, Journal of Turbomachinery, 110, 66-72.

Milovanov, V.K., 1985, "Some characteristics of flow in turbine blades with film cooling," Soviet Aeronautics, 28(3), 110113.
Stepka, F.S. and Gaugler, R.E., 1983, "Comparison of predicted and experimental external heat transfer around a film cooled cylinder in crossflow," ASME, 83-GT-47; also 1981, NASA TM-83017.

Tillman, E.S. and Jen, H.F., 1984, "Cooling airfoil studies at the leading edge of a film-cooled airfoil," ASME, Journal of Engineering for Gas Turbines and Power, 106, 214-221.

Tillman, E.S., Hartel, E.O. and Jen, H.F., 1985, "The prediction of flow through leading edge holes in a film cooled airfoil with and without inserts," $A S M E$, Journal of Engineering for Gas Turbines and Power, 107, 92-98.

Turner, E.R., 1984, "Turbine airfoil gas side heat transfer," Turbine Engine Hot Section Technology (HOST), NASA CP2339 , pp. $351-363$.

Turner, E.R., Wilson, M.D., Hylton, L.D. and Kaufman, R.M., 1985, "Turbine vane external heat transfer - volume 1: analytical and experimental evaluation of surface heat transfer distributions with leading edge showerhead film cooling," NASA CR-174827.

Wadia, A.R. and Nealy, D.A., 1988, "Experimental simulation of turbine airfoil leading edge film cooling," ASME, Journal of Turbomachinery, 110, 226-232.

Weinberg, B.C., Wang, R.-J., Shamroth, S.J. and McDonald, H., 1984, "Calculation of two- and three-dimensional transonic cascade flow field using the Navier-Stokes equations," Turbine Engine Hot Section Technology (HOST), NASA CP-2339, pp. 365-372.

Winstanley, D.K., 1980, "Stagnation region gas film cooling experiments on the effects of density ratio with injection through laterally inclined holes and on the effects of geometry with injection through streamwise inclined holes," M.S. Thesis, Purdue University; also D.K. Winstanley and M.R. L'Ecuyer, Purdue University, Mechanical Engineering Department, Technical Report TSPC-TR-80-02.

Yang, R.J., Weinberg, B.C., Shamroth, S.J. and McDonald, H., 1985, "Turbine vane external heat transfer numerical - Vol. II: solutions of the Navier-Stokes equations for two- and three-dimensional turbine cascades with heat transfer," NASA CR-174828.

Yoshida, T., Takahara, K. and Kumagai, T., 1982, "Analysis and test of coolant flow and heat transfer of an advanced full-coverage film-cooled laminated turbine vane," $A S M E$, 82-GT-131.

\section{0-1998}

Alekseev, N.M., Zelengur, A.A., Mironov, B.P. and Tararin, V.N., 1994, "gas film cooling at coolant's injection along the surface of a cross-flowing cylinder," Heat Transfer 1994, Proceedings of the 10th International Heat Transfer Conference, Vol. 3, G.F. Hewitt (Ed.), Paper No. 4-EC-1, pp. 1-5.

Ames, F.E., 1998, "Aspects of vane film cooling with high turbulence: Part I - heat transfer," ASME, Journal of Turbomachinery, 120, 768-776. ${ }^{\dagger}$

Ames, F.E., 1998, "Aspects of vane film cooling with high turbulence: Part II - adiabatic effectiveness," $A S M E$, Journal of Turbomachinery, 120, 777-784

Ardey, S. and Fottner, L., 1997, "Flow field measurements on a large scale turbine cascade with leading edge film cooling by two rows of holes," ASME, 97-GT-524.

Ardey, S., Fottner, L., Beversdorff, M. and Weyer, H., 1997, "Laser-2-focus measurements on a turbine cascade with 
leading edge film cooling," Advanced Non-Intrusive Instrumentation for Propulsion Engines, 90th AGARD-PEP Symposium.

Ardey, S. and Fottner, L., 1998, "Test case: leading edge film cooling on the high pressure turbine cascade AGTB," Institut fur Strahlantriebe, Universitat der Bundeswehr Munchen, Institshericht $\mathrm{Nr} 98 / 01$.

Ardey, S. and Fottner, L., 1998, "A systematic experimental study on the aerodynamics of leading edge film cooling on a large scale high pressure turbine cascade," $A S M E$, 98-GT-434.

Arts, T., 1991, "Convective heat transfer with film cooling around a rotor blade," Modern Research Topics in Aerospace Propulsion, Springer-Verlag, New York Inc., G. Angelino et al. (Eds.), pp. 253-274. ${ }^{\dagger}$

Beeck, A., 1992, "Flow field investigations into the aerodynamic behavior of a highly loaded turbine cascade with cooling air injection at the leading edge," Ph.D. Thesis, University of the Federal Armed Forces, Munich (in German)

Beeck, A., 1993, "Investigation of the turbine blade leading edge flow field regarding cooling quenching," Universitat der Bundeswehr (University of the Federal Armed Forces), Munich, Fakultat fur Luft -und Raumfahrttechnik (Department of Aeronautics and Astronautics Technology), Institut fur Strahlantriebe, Institute No. LRT-WE 12-93/1 (in German).

Beeck, A., Fottner, L., Benz, E. and Wittig, S., 1993, "The aerodynamic effect of coolant ejection in the leading edge region of a film-cooled turbine blade," Heat Transfer and Cooling in Gas Turbines, AGARD-CP-527, Paper No. 35.

Benz, E. and Wittig, S., 1992, "Prediction of the interaction of coolant ejection with the main stream at the leading edge of a turbine blade: attached grid application," International Symposium Heat Transfer in Turbomachinery, Athens.

Benz, E., Wittig, S., Beeck, A. and Fottner, L., 1993, "Analysis of cooling jets near the leading edge of turbine blades," Computational and Experimental Assessment of Jets in Cross Flow, 72nd Fluid Dynamics Panel Meeting and Symposium, AGARD-CP-534, Paper No. 37.

Biba, S. and Schiffer, H.-P., 1997, "Modelling approach for the prediction of leading edge film cooling effectiveness," 13th International Symposium on Air Breathing Engines (ISABE), AIAA Publications, F.S. Billig (Ed.), Vol. 1, ISABE 97-7112, pp. 787-796.

Bohn, D., Kusterer, K. and Schonenborn, H., 1996, "3-D numerical simulation of the flow through a turbine blade cascade with cooling injection at the leading edge," $A S M E$, 96-GT-150.

Bohn, D. and Rungen, A., 1996, "Influence of rotor/statorinteraction on film cooling at the rotor leading edge," Technische Hochschule (Technical University) at Aachen, ETDE-DE-464 (in German).

Bohn, D., Becker, V. and Schonenborn, H., 1996, "3-D numerical simulation of a film-cooled and convection-cooled turbine blade with non-adiabatic walls," ISFMFE Conference, Beijing.

Bohn, D.E. and Becker, V.J., 1996, "Experimental and numerical investigation of the flow field at the leading edge of a film-cooled turbine guide vane," ISFMFE Conference, Beijing.

Bohn, D.E., Becker, V.J. and Rungen, A.U., 1996, "Analysis of the location of the stagnation line on a turbine guide vane with shower-head cooling: experimental and theoretical investigations," ASME and Cairo University, Proceedings of the International Congress on Fluid Dynamics and Propulsion, pp. 127-136, Cairo.

Bohn, D.E., Becker, V.J. and Rungen, A.U., 1997, "Experimental and numerical conjugate flow and heat transfer investigation of a shower-head cooled turbine guide vane," ASME, 97-GT-15.

Bohn, D.E., Becker, V.J. and Kusterer, K.A., 1997, "3-D conjugate flow and heat transfer calculations of a film-cooled turbine guide vane at different operation conditions," ASME, 97-GT-23.

Bohn, D., Heuer, T. and Kusterer, K., 1997, “3-D parametric study of a turbine vane with leading edge ejection: investigation of cooling flow phenomena and cooling efficiency at the leading edge," Eurotherm Conference, Greece.

Bohn, D., Becker, V., Kusterer, K., Ardey, S. and Fottner, L., 1997, "The influence of slot ejection and showerhead ejection on the 3-D flow field of a film-cooled turbine blade under consideration of side wall effects," 13th International Symposium on Air Breathing Engines (ISABE), AIAA Publications, F.S. Billig (Ed.), Vol. 2, ISABE 97-7162, pp. 1203-1213.

Bohn, D.E., Becker, V.J., Kusterer, K.A. and Rungen, A.U., 1997, "Improving the film cooling coverage of the leading edge of a first stage turbine guide vane: experimental and theoretical investigations of two different cooling designs," 3rd International Conference on Fluid Dynamic Measurement and Its Applications (ICFDMA), Beijing.

Bohn, D.E., Heuer, T. and Kusterer, K.A., 1997, "3-D conjugate flow and heat transfer investigations of a filmcooled turbine guide vane with different blowing ratios," ASME ASIA '97 Congress \& Exhibition, ASME, 97-AA-5, Singapore.

Bohn, D.E., Becker, V.J., Kusterer, K.A. and Rungen, A.U., 1998, "Experimental and numerical conjugate investigation of the blowing-ratio influence on the showerhead cooling efficiency," ASME, 98-GT-85.

Camci, C. and Arts, T., 1990, "An experimental convective heat transfer investigation around a film-cooled gas turbine blade," ASME, Journal of Turbomachinery, 112, 497-503. ${ }^{\dagger}$

Camci, C. and Arts, T., 1991, "Effect of incidence on wall heating rates and aerodynamics on a film cooled transonic turbine blade," ASME, Journal of Turbomachinery, 113, $493-501 .^{\dagger}$

Chen, P.H., 1990, "Shower-head film cooling of a gas turbine blade," National Science Council, Report NSC-79-0401-E$002-20$.

Chen, P.H., 1992, "Shower-head film cooling in a highly turbulent flow field," National Science Council, Report NSC-80-0401-E-002-04

Chen, P.H., Kio, C.H., Myau, J.M., Shou, S.F. and Liu, M., 1993, "The convective transport phenomena over a turbine blade with a multi-row showerhead film cooling," Pacific International Conference in Aerospace Science and Technology, Taiwan, pp. 1243-1250.

Chen, P.H., Miao, Z.M. and Chan, H.C., 1994, "Stagnation film cooling: influence of mainstream turbulence on heat (mass) transfer," Proceeding of the 2nd National Heat Transfer and Fluid Flow Conference, Chuang-Li, pp. 55-57.

Chen, P.-H., Miao, Z.-M. and Chen, J.-W., 1994, "Convective transport phenomena for stagnation film cooling," Heat Transfer in Gas Turbines, ASME, HTD-Vol. 300, M.K. Chyu and N.V. Nirmalan (Eds.), pp. 31-44.

Chen, P.H. and Miao, J.M., 1996, "Effect of upstream wake on shower-head film cooling," International Journal of Rotating Machinery, 2, 269-280. 
Chen, P.H. and Miao, J.-M., 1996, "Film cooling effectiveness over a shower-head film-cooled turbine blade," Bulletin of the College of Engineering, National Taiwan University, No. 66, pp. 51-69.

Chen, P.H. and Miao, Z.M., 1996, "Effect of upstream wake on convective transport phenomena over a circular cylinder with stagnation film cooling," Proceedings of the 38th National Aeronautical and Aerospace Conference, Taipei, pp. 707-714.

Chen, P.H. and Miao, Z.M., 1996, "Effect of upstream wake on shower-head film cooling," The 9th International Symposium on Transport Phenomena in Thermal-Fluids Engineering, Singapore, pp. 1066-1072.

Chernobrovkin, A. and Lakshminarayana, B., 1998, "Numerical simulation and aerothermal physics of leading edge film cooling," ASME, 98-GT-504.

Colantuoni, S., Colella, A., Di Nola, L., Carbone, D. and Marotta, D., 1992, "Aero thermal design of a cooled transonic NGV and comparison with experimental results," Heat Transfer and Cooling in Gas Turbines, AGARD-CP-527, Paper No. 33. ${ }^{\dagger}$

Cruse, M.W., Yuki, U.M. and Bogard, D.G., 1997, "Investigation of various parametric influences on leading edge film cooling," ASME, 97-GT-296.

Cruse, M.W., 1997, "A study of film cooling adiabatic effectiveness for turbine blade leading edges," M.S. Thesis, The University of Texas at Austin.

Du, H., 1996, "Detailed film cooling measurement for a gas turbine blade with air and $\mathrm{CO}_{2}$ injection," Ph.D. Thesis, Texas A\&M University. ${ }^{\dagger}$

Du, H., Han, J.C. and Ekkad, S.V., 1997, "Effect of unsteady wake on detailed heat transfer coefficient and film effectiveness distributions for a gas turbine blade," $A S M E, 97-\mathrm{GT}-166 .^{\dagger}$

Du, H., Han, J.C. and Ekkad, S.V., 1997, "Detailed film cooling measurements over a gas turbine blade using a transient liquid crystal image technique," Heat Transfer in Gas Turbine Systems, ASME Proceedings of the National Heat Transfer Conference, Vol. 12, D.M. McEligot and D.G. Bogard (Eds.), HTD-Vol. 350, pp. 245-254.

Du, H., Ekkad, S.V. and Han, J.-C., 1998, "Effect of unsteady wake with trailing edge coolant ejection on film cooling performance for a gas turbine blade," ASME, 98-GT-259..$^{\dagger}$

Ekkad, S.V., Du, H. and Han, J.-C., 1995, "Local heat transfer cofficient and film effectiveness distributions on a cylindrical leading edge model using a transient liquid crystal image method," $A S M E$, 95-WA/HT-3.

Ekkad, S.V., Han, J.-C. and Du, H., 1997, "Detailed film cooling measurements on a cylindrical leading edge model: effect of free-stream turbulence and coolant density," $A S M E$, 97-GT-181.

Ekkad, S.V., Mehendale, A.B., Han, J.C. and Lee, C.P., 1997, "Combined effect of grid turbulence and unsteady wake on film effectiveness and heat transfer coefficient of a gas turbine blade with air and $\mathrm{CO}_{2}$ film injection," $A S M E$, Journal of Turbomachinery, 119, 594-600.

Ekkad, S.V., Krishna, A. and Han, J.C., 1998, "Detailed film cooling measurements on a cylindrical model with simulated TBC spallation," 7th AIAA/ASME Joint Thermophysics and Heat Transfer Conference, Vol. 4, pp. $69-76$.

Elfert, M., 1995., "Film cooling of turbine blade leading edge," Deutsche Forschungsanstalt fuer Luft- und Ramfahrt (German Research Institute for Aeronautics and Astronautics) e.V. (DLR), Koelin (DE), Institute fuer Antriebstechnik (for Propulsion Technology), HTGT-Turbotherm, Stage 2. Subproject 2.1.8.1 A and B: Final Report (in German).
Forghan, F., 1996, "Transonic turbine blade film cooling with shaped holes," Ph.D. Thesis, Northeastern University.

Fukuyama, Y., Otomo, F., Sato, M., Kobayashi, Y. and Matsuzaki, H., 1994, "Experiments on the film cooling effectiveness of bluff head gas turbine vane," Proceedings of 22nd Annual Gas Turbine Conference, pp. 56-62 (in Japanese)

Funazaki, K., Yokota, M. and Yamawaki, S., 1995, "Effect of periodic passing wake on the leading edge film cooling effectiveness: studies on 90-degree-inclination cooling holes," Transaction of the Japan Society of Mechanical Engineers (JSME) (B), 61(587), p. 2698 (in Japanese).

Funazaki, K., Yokota, M. and Yamawaki, S., 1995, "Effects of free-stream turbulence and periodic wake passing on the leading edge film cooling of turbine blades (heat transfer and heat load distribution)," 1995 Fall Annual Conference, Gas Turbine Society of Japan (abstract).

Funazaki, K., Yokota, M. and Yamawaki, S., 1997, "Effect of periodic wake passing on film effectiveness of discrete cooling holes around the leading edge of a blunt body," ASME, Journal of Turbomachinery, 119, 292-301.

Funazaki, K., Koyabu, E. and Yamawaki, S., 1998, "Effect of periodic wake passing on film effectiveness of inclined discrete cooling holes around the leading edge of a blunt body," ASME, Journal of Turbomachinery, 120, 70-78; also T. Maya et al., 1995, Proceedings of Yokohama International Gas Turbine Congress, Vol. 2, Gas Turbine Society of Japan, pp. $239-246$.

Garg, V.K. and Gaugler, R.E., 1996, "Leading edge film cooling effects on turbine blade heat transfer," Numerical Heat Transfer, Part A, Applications, 30, 165-187; also 1995, $A S M E, 95-\mathrm{GT}-275$.

Garg, V.K., 1996, "Adiabatic effectiveness and heat transfer coefficient on a film-cooled rotating blade," $A S M E$, 96-GT-221.

Garg, V.K. and Ameri, A.A., 1997, "Comparison of twoequation turbulence models for prediction of heat transfer on film-cooled turbine blades," ASME, 97-GT-24.

Garg, V.K. and Gaugler, R.E., 1997, "Effect of coolant temperature and mass flow on film cooling of turbine blades," International Journal of Heat and Mass Transfer, 40(2), 435-445; also 1995, ASME, 95-WA/HT-1 and $N A S A$ TM-112760. ${ }^{\dagger}$

Garg, V.K. and Gaugler, R.E., 1997, "Effect of velocity and temperature distribution at the hole exit on film cooling of turbine blades," ASME, Journal of Turbomachinery, 119, 343-351; also 1995, NASA TM-106954.

Garg, V.K. and Abhari, R.S., 1997, "Comparison of predicted and experimental Nusselt number for a film-cooled rotating blade," International Journal of Heat and Fluid Flow, 18, 452460; also 1996, ASME, 96-GT-223 (condensed version). ${ }^{\dagger}$

Garg, V.K. and Rigby, D.L., 1998, "Heat transfer on a filmcooled blade - effect of hole physics," $A S M E$, 98-GT-404; also NASA CR-1998-206609.

Gartshore, I.S., Salcudean, M., Barnea, Y., Zhang, K. and Aghadsi, F., 1993, "Some effects of coolant density on film cooling effectiveness," ASME, 93-GT-76.

Hall, E.J., Topp, D.A. and Delaney, R.A., 1994, “Aerodynamic/heat transfer analysis of discrete site film-cooled turbine airfoils," AIAA 94-3070.

Haendler, M., Raake, D. and Scheurlen, M., 1997, “Aerothermal design and testing of advanced turbine blades," ASME, 97-GT-66.

Haslinger, W. and Hennecke, D.K., 1997, "Highly resolved distribution of adiabatic film cooling effectiveness for turbine 
leading edge film cooling," 13th International Symposium on Air Breathing Engines (ISABE), AIAA Publications, F.S Billig (Ed.), Vol. 1, ISABE 97-7113, pp. 797-806.

He, P., Salcudean, M. and Gartshore, I.S., 1995, "Computations of film cooling for the leading edge region of a turbine blade model," ASME, 95-GT-20.

He, P., Licu, D., Salcudean, M. and Gartshore, I.S., 1996 "Leading edge film cooling: computations and experiments including density effects," ASME, 96-GT-176.

Heidmann, J.D., 1995, "A numerical study of the effect of wake passing on turbine blade film cooling," AIAA 95-3044; also NASA TM-107077.

Heidmann, J.D., 1996, "The effect of wake passing on turbine blade film cooling," Ph.D. Thesis, Case Western Reserve University; also NASA TM-107380

Heidmann, J.D., Lucci, B.L. and Reshotko, E., 1997, "An experimental study of the effect of wake passing on turbine blade film cooling," ASME, 97-GT-255; also NASA TM-107425.

Hoffs, A., 1996, "Experimental investigations of heat transfer and film cooling effectiveness using the transient liquid crystal technique," Ph.D. Thesis, Swiss Federal Institute of Technology - Lausanne (EPFL).

Hoffs, A., Drost, U. and Bolcs, A., 1997, "An investigation of effectiveness and heat transfer on a showerhead-cooled cylinder," ASME, 97-GT-69.

Irmisch, S., 1995, "Simulation of film cooling aerodynamics with a 2D Navier-Stokes solver using unstructured meshes," ASME, 95-GT-24.

Jiang, H.W., 1994, "Effect of film injection on heat transfer coefficient and film effectiveness from a gas turbine blade," M.S. Thesis, Texas A\&M University. ${ }^{\dagger}$

Jiang, H.W. and Han, J.-C., 1996, "Effect of film hole row location on film effectiveness on a gas turbine blade," ASME, Journal of Heat Transfer, 118(3), 327-333. ${ }^{\dagger}$

Jung, K. and Hennecke, D.K., 1998, "Highly resolved distribution of heat transfer for turbine leading edge film cooling including Reynolds number and blowing rate effects," ASME, 98-GT-64.

Kercher, D.M. and Sousa, M.P., 1995, "Diffusion hole filmcooled airfoils," Air Force Propulsion Wright Laboratory, WL-TR-96-2032.

Karni, J. and Goldstein, R.J., 1990, "Surface injection effect on mass transfer from a cylinder in crossflow: a simulation of film cooling in the leading edge region of a turbine blade," ASME, Journal of Turbomachinery, 112(3), 418-427.

Kim, K.J., 1990, "Experimental study on heat transfer characteristics on a film-cooled cylinder," M.S. Thesis, Seoul National University.

Kim, B.G., Rhee, D.H. and Cho, H.H., 1997, "Heat (mass) transfer for flows around a film cooling jet and circular cylinder with compound angle orientations," 10th Symposium on Transport Phenomena in Thermal Science and Process Engineering, Vol. 1, pp. 203-208.

Lakshminarayana, B., 1996, Fluid Dynamics and Heat Transfer of Turbomachinery, John Wiley \& Sons, Inc., pp. 678-679, 684, 696-698.

Lee, J.S., Lee, T.S. and Lee, S.W., 1991, "Experimental study of mass transfer on a film cooled circular cylinder surface," Transaction of Korean Society of Mechanical Engineers, Vol. 5, pp. 1756-1762

Lee, T.S., Lee, J.S., Lee, S.W. and Kim, K., 1992, "Effect of injection hole position and blowing rate on mass transfer about a film-cooled cylinder," Transport Phenomena in Heat and Mass Transfer, Elsevier Science Publishers B.V., J.A. Reizes (Ed.), pp. 363-372; also 1990, 3rd International
Symposium on Transport Phenomena in Heat and Mass Transfer, Vol. 4, p. 1440

Lee, J.S., Ro, S.T. and Seo, H.J., 1993, "Effect of free-stream turbulence on film cooling over a cylinder surface," Proceedings of Colloquium on Turbomachinery-1993, Seoul National University, pp. 289-230.

Lee, J.S., Ro, S.T. and Seo, H.J., 1994, "Mass transfer effects of free-stream turbulence and horseshoe vortex formed at the upstream edge of film cooling jets about a cylinder surface," ASME, 94-GT-18

Licu, D.N., 1998, "Heat transfer characteristics in film cooling applications," Ph.D. Thesis, University of British Columbia

Liguo, L. and Zhaohui, L., 1993, "Impingement cooling with film coolant extraction in the airfoil leading edge region," 11th International Symposium on Air Breathing Engines (ISABE), AIAA Publications, F.S. Billig (Ed.), Vol. 2, ISABE 93-7078, pp. 804-808

Lin, Y.-L., Stephens, M.A. and Shih, T.I.-P., 1997, "Computation of leading-edge film cooling with injection through rows of compound-angle holes," ASME, 97-GT-298.

Martin, C.A. and Thole, K.A., 1997, "Leading edge film cooling conceptual design through CFD, Part I: a leading edge benchmark using CFD," University of Wisconsin, Mechanical Engineering Department, Convective Heat Transfer Laboratory, Report No. 97-1.

Martin, C.A., 1997, "Numerical simulations of leading edge film cooling flows for gas turbine airfoils," M.S. Thesis, University of Wisconsin.

Martin, C.A. and Thole, K.A., 1997, "A CFD benchmark study: leading edge film-cooling with compound angle injection," ASME, 97-GT-297.

Mayle, R.E. and Anderson, A., 1991, "Velocity and temperature profiles for stagnation film cooling," ASME, Journal of Turbomachinery, 113, 457-463.

Mehendale, A.B., 1991, "Effect of high turbulence on leading edge heat transfer and film cooling," Ph.D. Thesis, Texas A\&M University.

Mehendale, A.B. and Han, J.C., 1992, "Influence of high mainstream turbulence on leading edge film cooling heat transfer," ASME, Journal of Turbomachinery, 114, 707-715

Mehendale, A.B. and Han, J.C., 1992, "Influence of high mainstream turbulence on leading edge film cooling heat transfer: effect of film hole spacing," International Journal of Heat and Mass Transfer, 35(10), 2593-2604.

Mehendale, A.B., Ou, S. and Han, J.C., 1992, "Leading edge film cooling heat transfer including the effect of mainstream turbulence," Transport Phenomena in Heat and Mass Transfer, Elsevier Science Publishers B.V., J.A. Reizes (Ed.), pp. 304-315.

Mehendale, A.B., and Han, J.C., 1993, "Reynolds number effect on leading edge film effectiveness and heat transfer coefficient," International Journal of Heat and Mass Transfer, 36(5), 3723-3730.

Mehendale, A.B., Han, J.-C., Ou, S. and Lee, C.P., 1994, "Unsteady wake over a linear turbine blade cascade with air and $\mathrm{CO}_{2}$ film injection: Part II - effect on film effectiveness and heat transfer distributions," ASME, Journal of Turbomachinery, 116, 730-737..$^{\dagger}$

Mehendale, A.B., Ekkad, S.V. and Han, J.-C., 1994, "Mainstream turbulence effect on film effectiveness and heat transfer coefficient of a gas turbine blade with air and $\mathrm{CO}_{2}$ film injection," International Journal of Heat and Mass Transfer, 37(17), 2707-2714.

Metzger, D.E. and Bunker, R.S., 1990, "Local heat transfer in internally cooled turbine airfoil leading edge regions: 
Part II - impingement cooling with film coolant extraction," ASME, Journal of Turbomachinery, 112, 459-466; also 1988, Heat Transfer in Gas Turbine Engines and Three-Dimensional Flows, E. Elovic et al. (Eds.), HTD-Vol. 103, pp. 65-75.

Miao, J.-M. and Chen, P.-H., 1998, "The convective transport phenomena over a turbine blade near the end-wall region with and without film cooling," Proceedings of the ASME Heat Transfer Division, Application of Heat Transfer in Equipment, Systems, and Education, L.A. Swanson et al. (Eds.), HTD-Vol. 361-3/PIP-Vol. 3, pp. 411-424.

Nirmalan, N.V. and Hylton, L.D., 1990, "An experimental study of turbine vane heat transfer with leading edge and downstream film cooling," ASME, Journal of Turbomachinery, 112, 477-487. ${ }^{\dagger}$

Ou, S., 1991, "Leading edge film cooling heat transfer including the effect of mainstream turbulence," Ph.D. Thesis, Texas A\&M University.

Ou, S., Mehendale, A.B. and Han, J.C., 1992, "Influence of high mainstream turbulence on leading edge film cooling heat transfer: effect on film hole row location," $A S M E$, Journal of Turbomachinery, 114, 716-723.

$\mathrm{Ou}$, S. and Han, J.C., 1992, "Influence of mainstream turbulence on leading edge film cooling heat transfer through two rows of inclined film slots," ASME, Journal of Turbomachinery, 114, 724-733.

Ou, S. and Han, J.C., 1994, "Leading edge film cooling heat transfer through one row of inclined film slots and holes including mainstream turbulence effects," ASME, Journal of Heat Transfer, 116, 561-569.

Ou, S., Han, J.C., Mehendale, A.B. and Lee, C.P., 1994, "Unsteady wake over a linear turbine blade cascade with air and $\mathrm{CO}_{2}$ film injection: Part 1 - effect on heat transfer coefficients," ASME, Journal of Turbomachinery, 116, $721-729 .^{\dagger}$

Richter, J., Jung, K. and Hennecke, D.K., 1996, "An investigation of heat transfer by leading edge film cooling applying the naphthalene sublimation technique," $A S M E$, 96-GT-463.

Salcudean, M., Gartshore, I., Zhang, K. and McLean, I., 1994, "An experimental study of film cooling effectiveness near the leading edge of a turbine blade," ASME, Journal of Turbomachinery, 116, 71-79.

Salcudean, M., Gartshore, I., Zhang, K. and Barnea, Y., 1994 "Leading edge film cooling of a turbine blade model through single and double row injection: effects of coolant density," ASME, 94-GT-2.

Schiffer, H.-P. and Biba, S., 1998, "Model for the prediction of heat transfer coefficients in the leading edge region of film cooled turbine blades," AIAA 98-4028.
Seo, H.J., 1993, "An experimental study of flow and heat transfer characteristics about a film cooled cylinder," M.S. Thesis, Seoul National University.

Sio, J., Kuk, K., Lee, J.S. and Lee, S.W., 1994, "Effect of freestream turbulence on film-cooled upstream of injection hole on a cylindrical surface," Transactions of the Korean Society of Mechanical Engineers (KSME), 18(3), 645-652.

Thakur, S., Wright, J. and Shyy, W., 1997, "Computation of a leading-edge film cooling flow over an experimental geometry," ASME, 97-GT-381.

Vogel, D.T., 1994, "Navier-Stokes calculation of turbine flows with film cooling," Proceedings of the 19th Congress of the International Council of the Aeronautical Sciences, AIAA, Vol. 2, ICAS-94-2.5.3, pp. 1572-1586.

Vogel, D.T., 1996, "Navier-Stokes simulation of the flow around a leading edge film-cooled turbine blade including the interior cooling system and comparison with experimental data," ASME, 96-GT-71.

Yamamoto, A. et al., 1995, "Three-dimensional flows in a turbine blade row with leading-edge coolant injection," 1995 Fall Annual Conference of the Gas Turbine Society of Japan.

Yamamoto, A., Kondo, Y. and Murao, R., 1991, "Cooling-air injection into secondary flow and loss fields within a linear turbine cascade," ASME, Journal of Turbomachinery, 113, $375-383{ }^{\dagger}$

Yuki, U.M., Bogard, D.G. and Cutbirth, J.M., 1998, "Effect of coolant injection on heat transfer for a simulated turbine airfoil leading edge," ASME, 98-GT-431.

Yuki, U.M., 1998, "Heat transfer and adiabatic effectiveness measurements on a simulated film-cooled turbine blade leading edge," M.S. Thesis, The University of Texas at Austin.

\section{Acknowledgments}

Special thanks and appreciation to Ms. Sandra Moltz of the GE Aircraft Engines Lynn library for her assistance in this research. Without the outstanding resources of the GEAE and MIT library systems, the extent of this bibliography would not have been possible. 


\section{ait \\ ENERGY MATERIALS}

M A N E Y publishing

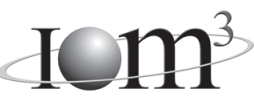

\section{Materials Science \& Engineering for Energy Systems}

Maney Publishing on behalf of the Institute of Materials, Minerals and Mining

The Institute of Materials, Minerals \& Mining

Economic and environmental factors are creating ever greater pressures for the efficient generation, transmission and use of energy. Materials developments are crucial to progress in all these areas: to innovation in design; to extending lifetime and maintenance intervals; and to successful operation in more demanding environments. Drawing together the broad community with interests in these areas, Energy Materials addresses materials needs in future energy generation, transmission, utilisation, conservation and storage. The journal covers thermal generation and gas turbines; renewable power (wind, wave, tidal, hydro, solar and geothermal); fuel cells (low and high temperature); materials issues relevant to biomass and biotechnology; nuclear power generation (fission and fusion); hydrogen generation and storage in the context of the 'hydrogen economy'; and the transmission and storage of the energy produced.

As well as publishing high-quality peer-reviewed research, Energy Materials promotes discussion of issues common to all sectors, through commissioned reviews and commentaries. The journal includes coverage of energy economics and policy, and broader social issues, since the political and legislative context influence research and investment decisions.

\section{CALL FOR PAPERS}

Contributions to the journal should be submitted online at http://ema.edmgr.com

To view the Notes for Contributors please visit: www.maney.co.uk/journals/notes/ema

Upon publication in 2006, this journal will be available via the Ingenta Connect journals service. To view free sample content online visit: www.ingentaconnect.com/content/maney

For further information please contact:

Maney Publishing UK

Tel: +44 (0)113 2497481 Fax: +44 (0)1132486983 Email: subscriptions@maney.co.uk

or

Maney Publishing North America

Tel (toll free): 8662975154 Fax: 6173546875 Email: maney@maneyusa.com

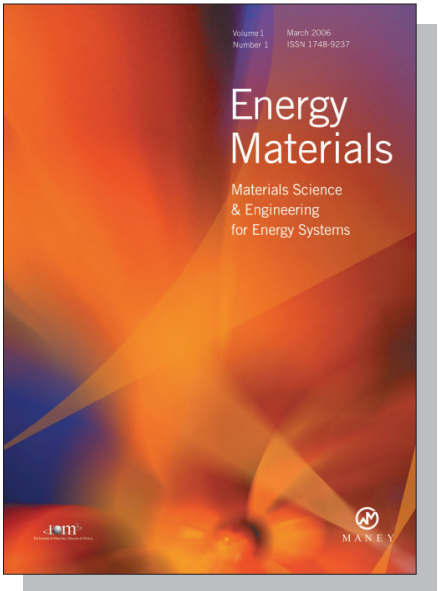

EDITORS

Dr Fujio Abe

NIMS, Japan

Dr John Hald, IPL-MPT, Technical University of Denmark, Denmark

Dr R Viswanathan, EPRI, USA

\section{SUBSCRIPTION INFORMATION}

Volume 1 (2006), 4 issues per year

Print ISSN: 1748-9237 Online ISSN: 1748-9245

Individual rate: $£ 76.00 / U S \$ 141.00$

Institutional rate: $£ 235.00 /$ US $\$ 435.00$

Online-only institutional rate: $£ 199.00 / U S \$ 367.00$

For special $\mathrm{IOM}^{3}$ member rates please email

subscriptions@maney.co.uk

\section{For further information or to subscribe online please visit www.maney.co.uk}



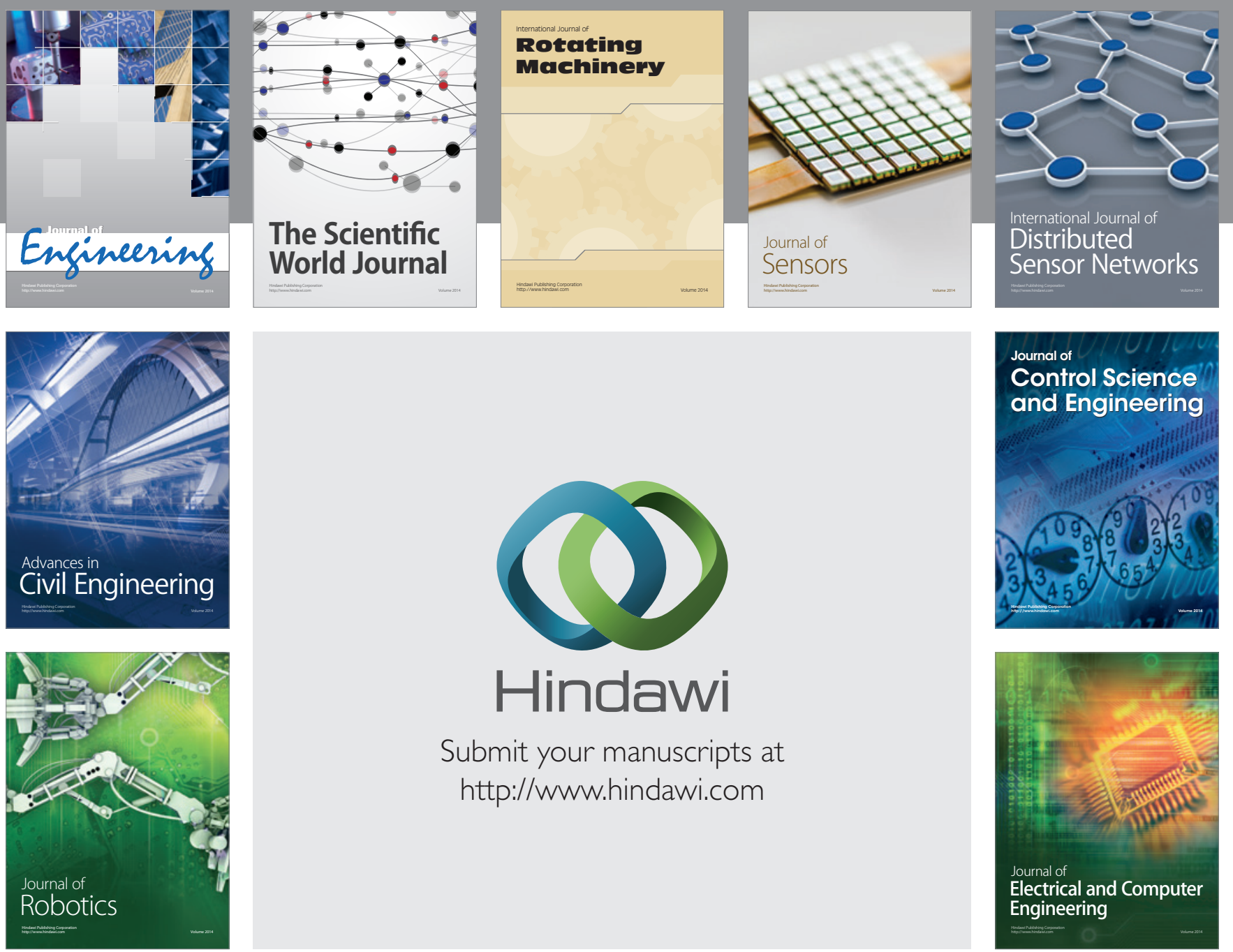

Submit your manuscripts at

http://www.hindawi.com
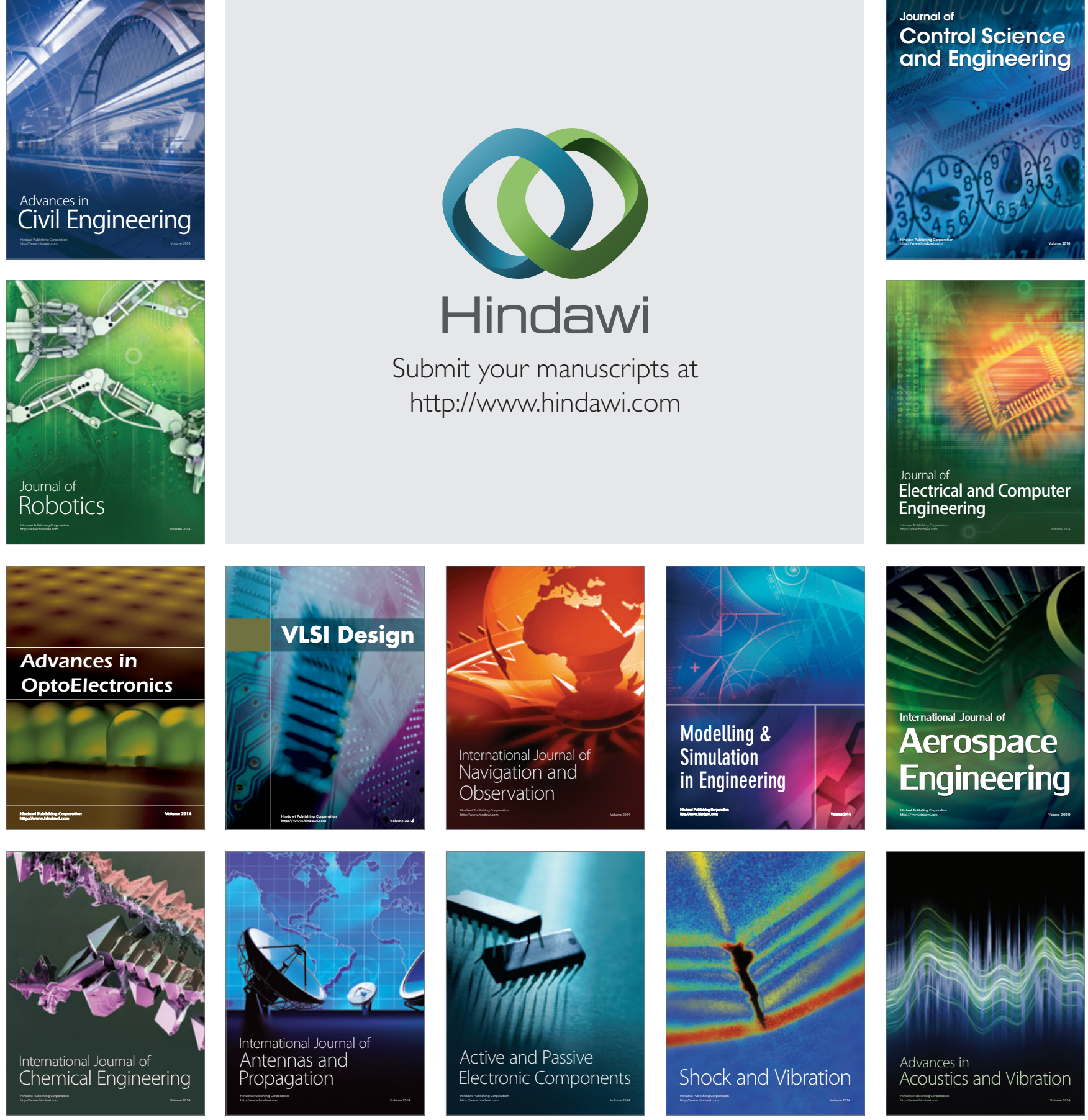